\title{
From Post-Punk to PC Music: Subcultural Discourses and Practices in Two Underground Scenes $(1979,2015)$
}

Du post-punk à PC Music : discours et pratiques subculturelles dans deux scènes underground $(1979,2015)$

\section{Philippe Birgy}

\section{(2) OpenEdition}

\section{Journals}

\section{Electronic version}

URL: https://journals.openedition.org/rfcb/8240

DOI: $10.4000 /$ rfcb.8240

ISSN: 2429-4373

\section{Publisher}

CRECIB - Centre de recherche et d'études en civilisation britannique

\section{Electronic reference}

Philippe Birgy, "From Post-Punk to PC Music: Subcultural Discourses and Practices in Two Underground Scenes (1979, 2015)", Revue Française de Civilisation Britannique [Online], XXVI-3 | 2021, Online since 14 December 2021, connection on 05 January 2022. URL: http:// journals.openedition.org/rfcb/8240 ; DOI: https://doi.org/10.4000/rfcb.8240

This text was automatically generated on 5 January 2022.

\section{cc) (1) 8}

Revue française de civilisation britannique est mis à disposition selon les termes de la licence Creative Commons Attribution - Pas d'Utilisation Commerciale - Pas de Modification 4.0 International. 


\title{
From Post-Punk to PC Music: Subcultural Discourses and Practices in Two Underground Scenes $(1979,2015)$
}

\author{
Du post-punk à PC Music : discours et pratiques subculturelles dans deux scènes \\ underground $(1979,2015)$
}

Philippe Birgy

\section{Introduction}

1 I propose to concentrate on two episodes in the history of popular music and its circulation. The first has been frequently chronicled and ultimately mythologized: I am talking of the proliferation in Great Britain, at the acme of the punk movement, of independent DIY labels which explicitly set themselves in opposition to the commercial mores of the larger record industry.

2 Here, the actual opposition and difference between underground and mainstream might appear, on the face of it, to be primarily a matter of discursive practices. But I do not want to jump to that conclusion and dismiss peremptorily the accusation of "selling out" to the industry as an ideological construct without having examined it. This is why I will review in the first part of my paper the main critical arguments that have been put forward in scientific literature since the 1980s on the subject of the modes of interaction between majors and independent record labels and the different degrees of their proximity. I take this to be a dialectical relationship, since the corporate record labels took interest in independent labels' new artists while the latter were attracted by the former's distribution network.

3 Contrasting with the example of the post-punk scene, I will then consider the very controversial case of the British electronic label PC Music, which rapidly moved from 
confidentiality to public visibility in 2014 and 2015. I will take PC Music as an example of the way the rise of electronic media has problematized the relation between mainstream and underground, though it has not eliminated their operations nor destroyed the significance of the dichotomy.

But first of all, I will say a few words about the definition of the term "underground". Stephen Graham observes that whether the word applies to a given music or not is "a matter of personal intuition." Nonetheless this statement is accompanied by a major caveat since, as he puts it, "this intuition will be situated within a context of rationally defined parameters of commercial appeal, musical style, ideology, industrial behaviour and allegiance, and so on". ${ }^{1}$

In other words, each of us has a personal interpretation of the qualifier "underground". Nonetheless, there are invariant criteria, and these are, according to Graham:

1. The abrasive quality of the sound, which offends good taste and frustrates the normal expectations of the listener. Let us note that it thereby defines itself in relation to the musical conventions that it flouts.

2. The fact that its operations are conducted outside or on the fringes of the main corporate or institutional circuits of distribution. This gesture of defiance is similar to the one I have just mentioned: it rejects commercialism and major corporations as well as institutionalized art forms.

3. Its reliance on authenticity, correlated with confidentiality. Again, this stands in opposition to the repackaging of music for mainstream exposure which, to the actors of the scene, amounts to a betrayal of its original spirit.

4. An affinity with the political agenda of the extreme left (ditto: an anti-capitalistic reaction).

5. A preference for live events, which gives music a sense of place and anchors it in a site.

6. A high degree of involvement with the scene as opposed to the passive consumption of mainstream musical products. (Frank Zappa is supposed to have declared: "The mainstream comes to you, but you go to the underground"). ${ }^{2}$

What I have tried to bring out in my comments on this list is that each term is antithetical to another, and this leads me to think that, rather than a series of distinctive markers, what we should pay attention to primarily is the existence of friction areas, points of contention and discrepancy, which can be articulated as dichotomies such as authentic versus artificial, confidential versus spectacular, corporate versus independent.

\section{Punk and post-punk practices}

7 The singularity of punk was that it reconfigured the field of alternative culture because it consisted in a negative movement which reacted strongly against the baby boomers and the countercultural revolution they had brought about. Punks held the previous generation responsible for the standardization of the rock musical form (the predominance of the album over the single, the seriousness of progressive rock). Its specificity, then, was that it articulated a countercultural discourse which was against the counterculture, as it were. Of course, this is a simplification because an artistic commune such as Coum Transmissions transitioned seamlessly into the post punk era with the industrial music of Throbbing Gristle. Nonetheless it is generally acknowledged that the combative, agonistic impetus given by punk was what drove the 
post-punk enterprise, resulting in the emergence of a large number of small labels that flourished in the aftermath of punk.

Rough trade was the most famous, because it was the bridgehead of a whole network of national distribution named the Cartel that they ran from their record shop. But many other names deserve a mention here, if only to indicate the spectrum of the subgenres they showcased, such as those of 4AD which started in 1980 with help from Beggars' Banquet, Attrix Records (a Brighton label that grew out of a band who then started a record shop) and Industrial Records, managed by Coum Transmissions. Manchesterbased Factory records started in 1978 and memorably included Joy Division, New Order, A Certain Ratio, the Durutti Column and Happy Mondays on its roster. Fast Product, created in 1977 in Edinburgh, issued records by Human League, Gang of Four, the Mekons and Joy Division in the span of two years and a half. Good Vibrations, set up in Belfast, released the Buzzcocks' Spiral Scratch EP. I.R.S., whose products were distributed through A\&M, included the Go-Go's, R.E.M., the Alarm and the English Beat in their catalogue. Mute released albums by D.A.F., Depeche Mode, Erasure, Fad Gadget, New Order, Nitzer Ebb, Wire, Nick Cave and the Bad Seeds and Yazoo. Situation Two, an offshoot of Beggars' Banquet, which had a distribution deal with WEA at the time, was home to post-punk acts like the Associates, Biting Tongues, Nyam Nyam, Home Service, Lydia Lunch, Ministry and Gene Loves Jezebel. Small Wonder, that grew out of a record store in the East London borough signed the Cravats, Crass, Patrick Fitzgerald, the Carpettes, Leyton Buzzards, Punishment of Luxury, the Cure and Bauhaus.

9 I certainly lack room to mention all of those who significantly contributed to this spectacular outgrowth: many people are likely to recognize a familiar sound under the imprint of Postcard Records, Stiff Records, Twotone Records, Jungle Records, Object Music, or Oval. If I take the trouble to enumerate these, at the risk of tedium, it is also to remind my reader that such labels signed major artists with commercial potential, which is precisely the ground of the claim that the independents were in actual competition with the majors. Twotone Records, for instance once had three different acts on BBC's Top of the Pops at the same time (November 1979).

Hesmondhalgh insists on the importance of the specialist record shop in the constitution of the alternative post-punk network. It was a local place where the qualities of confidentiality and diversity were cultivated. Hesmondhalgh describes a surge in the number of specialist record shops in Britain between $1978(1,750)$ and 1983 $(2,370) .^{3} \mathrm{He}$ mentions Beggars Banquet (in London's Earls Court), Small Wonder (Walthamstow, East London), Good Vibrations (Belfast), Probe (Liverpool), Graduate (Dudley, West Midlands) and Rough Trade. Now, the interesting particularity of all these was that they gradually added to their activities the production of records, many of which had been made by their customers.

Distributors, too, were crucial to the rise of the indies. As Hwanho Choi puts it:

Setting up an alternative distribution channel is an inevitable step for the indie scene to stand against the mainstream music industry. This challenge would also ensure that their products can be stocked in shops. The distribution channel for independent music was indicated by the rise of specialist shops that formed their own record label. In addition, this change encouraged new independent labels. ${ }^{4}$

12 Already, in 1974, Hesmondhalgh explains, "the distribution arms of the major record companies working in the UK at the time [...] drastically reduced their services to small retailers as they shifted their priorities away from dealer service to media marketing 
and promotion". ${ }^{5}$ Leaving the small shops in demand for sources of supply, the majors had caused independent wholesalers to step in. DIY labels relied on distributors such as Spartan (which started out in 1979 and established its own label shortly afterwards) and Pinnacle (a UK independent label active since the 1970s, expanding its operations as a distributor in the 1980s). Rough trade also started a system of national distribution, the Cartel, a co-operative organisation based on the association of regional distributors which was gradually expanded and reinforced in time until, by the end of the eighties, it was strong enough to cater for the needs of larger stores.

Beyond the facts that I have just recapitulated, we step into a domain where descriptions, even though they are based upon common observations, differ widely. For early researchers of the Centre for Contemporary Cultural Studies, ${ }^{6}$ the inventiveness of subcultures was necessarily vitiated by the eruption of an entrepreneurial spirit and degraded by the priority given to a market-driven economy. They saw the phenomenon of crossover as a movement whereby a musical subculture lost its anchorage in a living scene constructed by committed participants. It was uprooted from its substrate in such a manner that it was depersonalized. Being forcibly removed from the system of symbolic exchanges and shared values that gave it its force, it unavoidably lost its authenticity. ${ }^{7}$

of course, it is a strong opposition between mainstream and underground which underlies such views. And a second divide between creativity and commerce is superimposed upon it. Such a construction implies an ambiguous relationship to the popular. For if being popular means making a deliberate effort to reach the largest number of listeners, then it immediately conjures up the specter of mass culture, normative and consumerist.

In this agonistic version of the battle between the indies and the majors, any encroachment upon the preserve of indie labels is liable to be seen as a threat. Among the accounts which dominated the representation of the record industry, one stated that the majors, sensing that there was a niche public for every subgenre, decided to emulate the functioning of the independents or to allow them to operate as subdivisions of their company but with their own name, scouting departments and methods. This observation, which is basically accurate when all things are considered, acquired partisan overtones in the hands of the advocates of independent music. The majors, it was alleged, were obliged to develop this strategy because the heavy structure of their big companies was far less flexible than that of small labels. Hence, they had to rely on the latter's capacity to discover and nurture talents.

Stranchan also noted that DIY productions had been used as a marketable category, suggesting that the values of authenticity, counterculture and subversiveness had been glamorized and turned into selling points that could make a product attractive to customers. Graham mentions the "key marketing potential and function of the category "underground music."' ${ }^{8}$ That is: it offered the possibility to slot a band or artist into a category that could be promoted as such.

17 Another pivotal dichotomy in the adversarial discourse against the mainstream is that between diversity and heterogeneity on the one hand and homogenization and concentration on the other. It is consonant with Graham's observation that "the underground exists primarily as a globally determined homogeneity with local divergences of culture and politics". (46) A profusion of scenes, genres and sub-genres, flourished under the post-punk umbrella. These were federated by their common 
distributor, and it is that network of interrelated scenes and neotribes that eventually became a whole field of alternative music: the indies, with their magazines and their charts (the first indie chart in the UK appeared in 1980). In this way, Simon Frith could write in 1988 of an accommodation between the majors and the independents that was "dependent on the fragmentation of pop taste". 9

Yet overall, in spite of the post-punk initiative, the globalization of the music industry had centralized tastes even more, making all earnings reliant upon a reduced number of superstars. This fact was compounded by the extreme concentration in the recorded music industry: From 1988 to 1999,85 per cent of the activity was in the hands of six companies. In 2014, the AIM estimated that three majors had a collective global market share of some 65 to 70 per cent. In 2016 it was down to two thirds, but in the UK that figure still rose to 77 per cent. ${ }^{10}$

As I have indicated before, distribution was the crucial factor for independent labels, and that is why many of these accepted contracts with major labels to spread their products. ${ }^{11}$ But as commentators have remarked, it was often the first step towards absorption of small labels within the larger structure. For instance, Food Records was distributed through Rough Trade, and it also licensed acts though WEA Records. EMI invested in the label and in 1994 it gained complete control and absorbed it into Parlophone, a division of EMI which in turn was bought by Warner music in 2000.

At the very least, there is one comment I can safely make at this stage: there appears to be no firm dividing line between underground and mainstream but a series of intermediate zones, a continuum along which a scene or an artist associated to it gradually moves from confidentiality to a more widespread recognition. An unsigned artist may be of interest to a small independent label that will press 1,000 to 2,000 copies. Now, to move that quantity of merchandise, one must already have at least a distributor and possibly some form of promotion or other: Rough trade was known for providing these services to self-produced artists. And the growth in reputation resulting from that exposure might attract the attention of some in-house label of a major company which would sign the artist and press 20,000 copies of an album. And so on and so forth. Consider the case of Joy Division : 1,000 copies of their first EP, An Ideal for Living, were pressed and released on the band's own label in June 1978. They were consequently signed to Factory Records. Unknown Pleasures was initially printed in a run of 10,000 copies, with 5,000 copies being sold within the first two weeks of release, and a further 10,000 copies being sold over the following six months. As regards Closer, their posthumous album released in July 1980, 250,000 copies were sold worldwide in the two following years.

21 Of course, the threshold differs according to the potential appeal of the artist: Throbbing Gristle- The Second AnnualReport was first released as a limited edition of 785 copies on Industrial Records, the bands' own label, in 1977. When it was reissued in 79 on Fetish Records, 2000 copies were pressed. Subsequently, it was re-pressed by Mute. ${ }^{12}$

\section{The interplay between Majors and Indies}

22 As opposed to the agonistic model of the relationship between indies and majors, and against the heroic or mystical narrative in which the majors are represented poaching the roosters of independent labels, Negus makes the case for a collaboration between them. He generally endeavours to debunk the myth of predation by the majors. As he 
phrases it, "an industry produces culture and culture produces an industry." All in all, Negus concludes that "the absorption of independent labels has been a feature of the music business throughout the twentieth century and has become increasingly institutionalized through a series of joint ventures, production, licensing, marketing and distribution deals which have led to the blurring of 'indie'/'major' organizational distinctions and belief systems." ${ }^{13}$ In Hesmondhalgh's estimate, the difference between the two has gradually eroded. Ryan Moore concurs: "Many scholars have demonstrated that the boundaries between subculture and mass culture are in reality more fluid than rigid". ${ }^{14}$ Relying on Frith's research, Hesmondhalgh argues for symbiotic relationships between majors and indies. He also references Burnett who gives evidence that both concentration and diversity have increased in the eighties as a result of the collaboration between independents and majors. ${ }^{15}$ Strachan suggests that all the talk of a battle waged between the indies and the majors to defend esthetic values against the encroachment of commercialism is an overstatement, for the independents never achieved a critical mass sufficient to offset the dominance of the majors. ${ }^{16}$

More elusive yet perhaps more decisive, there is a negative dialectic which undergirds the conceptualization of the indies and the majors as mutually exclusive realities. Graham, quoting Tagg, observes that the underground, although it is exclusive of the mainstream and rejects its modes of operation, relies upon the existence of a rich parent culture and "its production and distribution is to a large extent only possible in an industrial monetary economy". ${ }^{17}$ It requires an urban concentration which is correlated to economic growth and also provides a potential public of musically curious individuals. A number of social places dedicated to culture are equally required, offering venues for its events, although the underground distances itself from the public sphere.

Another aspect of this oppositional dynamic, still, manifests itself as an unceasing interaction with the music industry, so that artists and bands fashion their artistic persona and their style in response to it, in a dialogical relationship. Whether they reject it or not, it determines their esthetic choices, their self-presentation and public image. ${ }^{18}$

As for the binary authenticity/facticity, I would suggest that all people involved in post-punk were very ambivalent about their legitimacy. One may incriminate the cumbersome legacy of Rock'n'Roll which, after all, had been borrowed from the USA, thus compromising all British claims to authenticity. Punk itself had been naturalized insofar as it drew its inspiration from the American proto-punk of Iggy Pop, the New York Dolls, Richard Hell and the Ramones.) It might be that Great Britons felt a special sense of entitlement to the products and achievements of American subcultures, which assuaged their misgivings. Yet one must remember that in the hands of McLaren, Punk was already "the great Rock'n'Roll swindle" (after the title of Julien Temple's 1980 movie which dramatizes the subject), and those who had worked their way to the top through the alternative network of punk were charged with having squandered its vital forces or traded them against financial success.

Associated to these previous dichotomies, that of public success and secrecy also proves problematic. The post-punk scenes may well have drawn from punk the principles of rejection and refutation which had given it a negative twist, but they also incorporated its contradictions. For this defiant attitude was combined in punk with a heightened visibility, a form of exhibitionism, a preference for shock tactics, a determination to 
place themselves under the collective gaze, so that its incongruity would obtrude upon the prevailing consensus, exposing the bland sameness of its conventions. ${ }^{19}$ Will Straw, conscious of this aporia, contends that the underground "contributes to the theatricality of cities." ${ }^{20}$ However elusive and hidden from view, it "participates in the spectacle of visual diversity" of the town. This spectacularity is remarkably similar to the strategies of punk, and before that, it was already an essential feature of the avantgardes whose constitutive paradox is that they imposed themselves as a spectacle, yet insisted on the confidentiality and secrecy of their activities - just as they betrayed an elitist bias yet were determined to occupy the field of the popular and obdurately pursue original expression in that unlikely environment. (This stress laid on expression is something we will also find in PC Music.) As Straw points out: "as obscure worlds whose logics and practices often escape easy identification, musical undergrounds enhance the sense that key features of contemporary urban life are invisible, indecipherable, mysterious." In their obscurity, they function as a cryptic or sibylline inscription, which gives a meaningful depth to the alternative scene in absentia. Thus, they remove themselves from common experience and common understanding.

The same evidently applies to Post Punk. It enhanced its visibility but simultaneously eluded publicity and became inscrutable because any excessive exposure might have endangered its life.

A secret, as Derrida argued, is a public thing. After all, there is no secrecy if no one knows that something is being kept away from them. And this thing cannot be elucidated or revealed or unlocked without losing its power of suggestion, the horizon of meaning that it had promised. ${ }^{21}$

Ryan Moore ${ }^{22}$ proposes that a structural transformation has affected post-modernity: increased turnover of artists, flexibilization of the labor market and discontinuity and fragmentation of musical preferences are all defined by the market. The industry aims at fleeting tastes, at niche markets which are incessantly renewed. Everyday life is invaded by commodities. The stream of images and products to which youth are exposed has accelerated. Punk youth responded to it by parodying these styles and images. This semiotic warfare was coextensive with the DIY spirit that animated punk at first and prompted the creation of fanzines and parallel networks of distribution. Reynolds in "New Pop and its Aftermath" ${ }^{23}$ observed that after 1979, punk had solidified into a dogmatic purism exclusive of every musical innovation that might suggest a move towards pop. Conversely, such gesture in the direction of the popular is precisely what characterizes post-punk. Hesmondhalgh uses the case of Scritti Politti, signed on Rough Trade, to illustrate that trend. With an art school background, the band - and more particularly its front man - had been increasingly dissatisfied by the exclusion of pop from alternative music and they responded by developing what Hesmondhalgh terms a "populist esthetic" in a bid to reclaim the popular. ${ }^{24}$

31 Other arguments, still, might be advanced to substantiate the claim that the mainstream and the underground supported each other within their conflictual relationship. Punks, as Hebdige has it, stood out from previous subcultures by the use they made of mass market commodities associated to mainstream circulation. ${ }^{25}$ They started from participation in the consumption of media and commercial goods, only to adapt them to their needs, distorting them and twisting them so that they fitted their personal or collective intention. They both evaded the market and proceeded from it. Rather than focusing on the act of consumption, cultural studies chose to emphasize 
the share of creativeness or cultural production involved in the process, so as to demonstrate that youth were the authors of the subcultures within which they moved about. "From this alternative perspective", Negus comments, "the capitalist organisation of popular music production is irrelevant, because the creative possibilities are realised in the act of consumption". Yet the subcultural subject remains nonetheless involved in consumerism. ${ }^{26}$

\section{PC Music and the internet underground}

In the last part of this paper, I will consider the case of PC music, whose artists combined sonically disturbing elements - signaling a refusal to tame their disruptive contents for the sake of a consensual reception - with a pseudo-naïve exploitation of mainstream 90s electronic pop, paradoxically demarcating them as bubble gum music. And most significantly for our purpose, the label marketed no product and merely consisted in a Soundcloud account where the new productions (featuring fictional authors and performers - which made the attribution of authorship very difficult) were freely available.

Admittedly, there is a notable difference in scale between the spread and the impact of post-punk and those of PC Music and I do not offer the latter as a point of comparison. The latter's activities have been far too volatile to affect the economy tangibly or result in the creation of enduring material structures - although this dematerialization might be generally imputed to technological developments. To make it commensurable it would have to be included in the wider trend of British "hypnagogic pop" and of its American counterpart, Chillwave, most significantly its Vapourwave output whose appellation alone speaks volumes about its lability and evasiveness.

But to bridge the gap between the early eighties and the twenty-tens, a few preliminary remarks on the role of the internet in relation to musical subcultures are in order. To begin with, Ryan Moore argues that contemporary independent musical scenes since the noughties have been far less oppositional than they had been in the eighties and that the notion of entering a competition with the majors is not as salient today as it was in the discourse of the independents in the late 70s and early $80 \mathrm{~s}^{27}$

Now, many critics and journalists agree that the development of the underground has been facilitated by the internet, in spite of the prophecy that such exposure would breach the confidentiality that was deemed vital to that alternative milieu. Graham believes that the underground keeps its constitutive virtues of confidentiality and secrecy when it becomes accessible online because the abrasive character of its sound deters the general public. ${ }^{28}$

More critical commentators insist on the existence of two undergrounds, one physically grounded, requiring precise locales (which are constitutive of a scene) and another that has dematerialized, endangering the locality and the secrecy indispensable to its activities.

PC Music, founded in August 2013 by A. G. Cook, does not capitalize on any such sense of rootedness. Commentators insist the label is not dependent on its main locale (London) to assert its distinctive identity. Simon Franck argues that "PC Music cheerfully mangles the regional identity once so crucial to independent labels". Yet he ascribes a particular significance to its two most visible composers and producers 
having studied at Goldsmith College, though he does not specify which exactly, apart from the fact that the affiliation to a prestigious institution seems to imply the existence of some "offline social circle". ${ }^{29}$

PC Music's visibility was achieved by the sole means of its Soundcloud page which served both as digital publishing and promotion platform. On it, full tracks from various artists were available for online listening, some of which had passed over 100,000 listens by September 2014. Already, that uncertainty about the function of the Soundcloud account is notable: what could it promote since there was nothing to sell? Or if it was an online shop for the label, then what could its commercial rationale be, considering that all the songs could be played freely from the site? As Sam Wolfson wrote in The Guardian: "According to its founder, AG Cook, PC Music is just a record label. But a record label that has never officially signed anyone." It was only in November 2014 that one of the songs, Hannah Diamond's "Every Night", was sold online. ${ }^{30}$

39 As described by its supporters, PC Music is typified by youth, a passion for novelty and a general state of disaffection with the uses and institutions of the previous generation. Adam Harper stresses that "[ $t]$ he online underground don't send press releases to decades-old music magazines and websites (maybe some of them would if they thought it would have an effect.)" He adds that "the term 'online underground' [as he uses it] doesn't imply any one style or aesthetic, only a mode of distribution." ${ }^{31}$ So much for the general impression the label creates.

40 According to the usage of PC Music, confidentiality is enforced by a systematic fictionalizing and retouching of the identity of the label's protégés. Many of the artists' names are pseudos, presumably hiding the same musician behind several acts, leading to speculations in the press about the identity and gender of the artists. Communication with external media was limited from the onset and journalists were quick to pinpoint the role of anonymity in the artists' process of constructing their identity and public persona. Cook himself, in one of the rare interviews he gave, declared:

I've always enjoyed playing a bit of an A\&R role, not just through finding new music but also by embracing the major label concept of 'artistic development'. I particularly enjoy recording people who don't normally make music and treating them as if they're a major label artist. Often, we end up developing a really strong musical and visual identity, which is still kinda personal and idiosyncratic. Working with all these different personalities and styles has become a core part of how I think about music, to the extent where, for me, it's becoming a style in itself. ${ }^{32}$

41 One of the collaborators of PC Music, the Scottish producer SOPHIE has reputedly watched her own show "offstage disguised as a security guard while drag performer Jesse Hoffman pretended to DJ in her place", Michelle Lhooq comments. ${ }^{33}$ The producer's identity, which had remained enigmatic until the release of her first album, has led to many speculations until she eventually appeared physically in a clip ("It's okay to cry") as a transsexual woman. However, SOPHIE insists she's never been interested in anonymity. "I'm always honest in what I put across".

An aspect of PC Music that clearly sets it apart from of the late 1970s and early 1980s is the fact that the tensions between confidentiality and mass distribution, artistic integrity and commercialism, sincerity and corruption (mentioned in the first part of this paper), are neutralized in the discourse of the label's advocates. Adam Harper surmises that PC Music's message could be phrased as follows: "We might as well sound like this. In a world of gloss and accelerated desire, this is what society made us." "In 
this regard, they're punks," Harper comments. Ash Beks, alluding in particular to QT's song "Hey QT" (a collaboration between SOPHIE and PC Music which comes off as a promotional number for an imaginary energy drink named QT) declares that:

[t]he aesthetic and cognitive values of bubblegum bass are perhaps reminiscent of Andy Warhol and the pop art movement of the 1960s: re-appropriation, celebration/indignation [sic] of mass media and the dichotomy [sic] of consumerist/capitalist values share equal footing and it remains the burgeoning task of the audience and critic to decipher the art as they see fit.

The same song also caused Sam Wolfson to observe: "This isn't the language of creativity, I think, it's the language of marketing." SOPHIE does not deny the suggestion, far from it. In an interview in Billboard magazine, she readily answered the question "what genre do you coin yourself?" with this single word: "advertizing." About the McDonald's web spot which used one of her songs, she similarly declared: "If you can do two things with it, give it meaning for yourself according to the perspectives you want to share and also have it function on the mass market, and therefore expose your message to more people in a less elitist context, then that is an ideal place to be. An experimental idea doesn't have to be separated from a mainstream context. The really exciting thing is where those two things are together. That's where you can get real change". ${ }^{34}$

According to Geffen, SOPHIE defends "the idea that interacting with consumerism is actually more authentic and truer to the world as it is than keeping your music in a position of relative purity" and the artist seems to confirm that interpretation: "That's a running theme in this music - questioning preconceptions about what's real and authentic". ${ }^{35}$

Having acted as a co-producer for Madonna and Charli XCX, worked in the studio with Rihanna and embarked on a collaboration with Lady Gaga, she champions the notion of an identity that cannot be thought out in terms of genres and dichotomies such as elite and mainstream. A whole set of arguments that account for that embrace of commercialism as an aesthetics has been developed in the press: as opposed to the attachment of electronic musicians to older technologies, manifested in their use of vintage analog instruments, PC Music would espouse the technology of their time - a debatable point, since the production of PC Music abounds in mannerisms reminiscent of nineties trance anthems. E. G. Cook, for example, quotes the names of Jimmy Jam \& Terry Lewis which he regards with admiration and respect. In his Tank interview he admits that he likes "keeping track of the mega-producers who have been responsible for endless hits over the last decade or two - Max Martin is probably my favourite".

Commentators have also sensed in Cook and SOPHIE's rhetoric a deviation from the popular apprehension of what an underground and a mainstream consist in (although there is no historically sanctioned notion of what an underground should be). ${ }^{36}$ It might be that the relation to success has changed since the twenty-tens and that pop no longer designates the same object. DJ Louie XIV writes about a fracture between pop music as a genre and popular music. The former, he argues, is not the most popular music anymore. It is no longer the place where the aspiring performer may make a career. (The triumph of hip hop and R'n'B certainly accounts for this shift of interest). This new arrangement has brought about a dissociation between the standardized markers of success (such as chart positions) and actual popular success (as evidenced by public attendance). This is illustrated by Robyn's sold-out show at Madison Square 
Garden, "a feat once reserved for artists who've sold 100 times as many records as she has", DJ Louie XIV comments.

Such a configuration opens up a possibility for pop stardom without the media hype and general public attention that normally attend it. Conversely, it introduces in that pop status an uncanny element that, in all likelihood, should be divisive but is not, as Spotify and Instagram activity redefines the prize list in such a way that even without massive sales, pop artists served by a team of dedicated fans can fill up reputed venues. This results in an "alternative mainstream" made up of cumulated niche publics that are not listed in the usual nomenclature of clients and consumers.

More pessimistically, Danilo Bortoli suggests that the internet has favored modes of exchange and conversation that insulate us. It has encouraged a pluralism made of exclusive communities, each sharing the same views within their restricted community site and conversation group but blissfully ignoring one another. And these digital mores have eventually bled into our practices in everyday life. This would obviously spell the end of the popular, either in the sense of a unifying factor that brings together all communities or of a mass-selling commodity that is not necessarily conducive to a shared experience.

\section{Conclusion}

In 2005, Reynold had already delivered the final verdict:

The web has extinguished the idea of a true underground. It's too easy for anybody to find out anything now [...] And with all the mp3 and whole album blogs, it's totally easy to hear anything you want to hear, in this risk-less, desultory way that has no cost, either financially or emotionally. [...] it's hard for me to see the changes as anything other than dis-intensifying". ${ }^{37}$

50 Yet at the same time, the web also facilitates a coming together of like-minded participants, overcoming geographical distance and federating the most intensely involved actors into a scene. As Sam Wolfson notes, "Communication between PC Music artists happens mostly online, with songs and concepts fired back and forth between Cook and the diaspora of artists." ${ }^{38}$

But for all that, does PC Music present the required characteristic that would qualify it as underground? Experimentation is certainly present, as well as a criticism of consumer society. Confidentiality and anonymity also apply, at least in the first phase of its activities. It may be that we are dealing with two different acceptations of the term "underground" here. On the one hand, it is a factual term that designates the practical, empirical, process of formation of a tight-knit and exclusive scene. But on the other, it refers to a confidentiality which is in itself a subcultural capital ${ }^{39}$, a badge of honour that confers upon one a measure of distinction.

PC Music manifestly posits the possible collusion of commercial intent and creativeness, both as an aesthetic formula and a practical arrangement. To the critical observer, their stance may suggest that the opposition between mainstream and underground does not hold except as an unproblematic discourse of legitimization. They ignore the incompatibility between the terms and leave the content of such notions as experimentation, novelty and originality totally unexamined. For the rest, they act as if the two categories were porous, overlapped and passed into each other, as if they did not describe stable positions (in the same way that Marcus says about punk 
that it was an attempt to get at the general public through the channel of everyday life and dislocate its organization, although everyday life is normally the core and the thriving ground of ideology, of whatever justifies normalcy).

Frith had prophesized that the commercial and the artistic would eventually pass into one another in indie rock. ${ }^{40}$ What I hear in PC Music is an attempt to overcome the contradictions inherent to the site they occupy (these dichotomies that I have mentioned earlier). The discourse of their artists signals some utopian ambition to combine mutually exclusive terms (for example, they seem to fantasize a mass audience that would discriminate between what is honest and dishonest).

On the other hand, in the accusation of corruption of ethical, political or aesthetic principles which might be directed at them, there is a complete denial of the impermanence of any entrenched position of resistance worthy of the name underground. Hakim Bay used the word Temporary Autonomous Zones to describe the terms and conditions under which a utopian space of creative freedom could be set up and the main characteristic of TAZ, of course, is transience. It is not there to stay. As a matter of existence, it is just bound to change.

\section{BIBLIOGRAPHY}

Anon, "Independent Music is now a growing force in the global market", Musicindie.com, 1 February 2014, <http://www.musicindie.com/independent-music-now-growing-force-globalmarket/>, consulted 20 March 2019.

Anon, "Throbbing Gristle Second Annual Report Celluloid Lp, Popsike, no date, <https:// www.popsike.com/THROBBING-GRISTLE-Second-Annual-Report-CELLULOID-LP/ 380099070600.html>, consulted 20 March 2019.

Choi, Hwanho, "The New Wave of Independent Labels", dissertation (Liverpool: Liverpool University, 2009), <http://enoughrecords.scene.org/netaudio/Hwanho_Choi__he_New_Wave_of_Independent_Labels__Dissertation_.pdf>, >, consulted 25 March 2016. Derrida, Jacques. "I have a taste for the secret", A Taste for the Secret, Cambridge, Polity, 2001, pp. 4-92.

Frank, Simon, "Corporate DIY: PC Music and Performing Professionalism", LEAP 34, 11 December 2015, <http://www.leapleapleap.com/2015/12/corporate-diy-pc-music-and-performingprofessionalism/>, consulted 20 March 2019.

Frith, Stephen, Howard Horne, Art into Pop (London, Methuen, 1987).

Geffen, Sasha, "Sophie Can Show You the World, and she's changing pop music in the process", Vulture, December 2017, <https://www.vulture.com/2017/12/profile-sophie.html>, consulted 20 March 2019.

Golsorkhi-Ainslie, Sohrab, "Radio Tank Mix: A. G. Cook", no date, <https://tankmagazine.com/ tank/live-archive-music/radio-tank-mix-a-g-cook/>, consulted 20 March 2019. 
Graham, Stephen, Notes From The Underground: A Cultural, Political, and Aesthetic Mapping of Underground Music (PhD, Goldsmiths College, University of London, 2012).

Graham, Stephen, Sounds of the Underground: A Cultural, Political and Aesthetic Mapping of Underground and Fringe Music (Ann Arbor, MI, U of Michigan P, 2016).

Harper, Adam, “The online underground: A new kind of punk?", Resident Advisor, 22 Sep 2014, <https://www.residentadvisor.net/features/2137>, consulted 20 March 2019.

Hesmondhalgh, David, "Post-Punk's attempt to democratize the music industry: The success and failure of Rough Trade”, Popular Music 16, 3 (1998), pp. 255-274.

Hesmondhalgh, David, "Flexibility, Post-Fordism and the Music Industry", Media culture and Society, 18 (1996), pp. 469-488.

Lhooq, Michelle. "Pop Producer SOPHIE on Anonymity, Honesty, and Artifice”, Teen Vogue, 7 December 2017, <https://www.teenvogue.com/story/sophie-producer>, consulted 20 March 2019.

Marcus, Greil, Lipstick Traces: a Secret History of the Twentieth Century (London, Secker \& Warburg, 1989).

Michaud, Ginette, "La voix voilée. Derrida lecteur de soi (Fragment d'une lecture de Voiles)", Derrida lecteur, Ginette Michaud and Georges Leroux ed., Études françaises, 38,1-2 (2002), pp. 239261.

Moore, Ryan, "Alternative to what? Subcultural capital and the commercialization of a music scene”, Deviant Behavior, 26:3, 2005, pp. 229-252.

Negus, Keith, "Where the mystical meets the market: creativity and commerce in the production of popular music", Sociological Review, 43, 2 (2008), pp. 316 - 341.

Negus, Keith, Music Genres and Corporate Cultures (New York, Routledge, 1999).

Osgerby, Bill, "Issues and Debates", Subcultures, Popular Music and Social Change (Newcastle, Cambridge Scholars publishing, 2014), pp. 1-47.

Reynolds, Simon, "New Pop and its Aftermath", On Record: Rock, Pop and the Written Word, Simon Frith and Andrew Goodwin eds. (London, Routledge, 1985), pp. 466-71.

Reynolds, Simon, "Bring the noise: an interview with Simon Reynolds", Fact Magazine, 18 April 2007, <www.factmagazine.co.uk/da/53579>, consulted April 2008.

Strachan, Robert, "Micro-independent record labels in the UK: Discourse, DIY cultural production and the music industry", European Journal of Cultural Studies, 10, 2 (2007) pp. 245-65.

Straw, Will, "Above and below ground", Keep it Simple, Make it Fast! An approach to underground music scenes. Paula Guerra and Tania Moreira eds., Volume 1, proceedings of the 2014 KISMIF conference, pp. 407-13, <https://ler.letras.up.pt/uploads/ficheiros/13184.pdf>.

Street, John, Subcultures, Popular Music and Social Change (Cambridge Scholars Publishing, 2014).

Webb, Peter, "'Infected by the seed of post industrial punk bohemia': Nick Cave and the milieu of the 1980s underground", Popular Music History, 3, 2 (2008), pp. 103-122.

Wenham, Alison, "Independent Music is now a growing force in the global market", Musicindie.com. 1 February 2014. <http://www.musicindie.com/independent-music-now-growingforce-global-market/>, consulted 20 March 2019. 
Westcott Grant, Kristin, “U.K. Producer SOPHIE Q\&A: On Secrecy, Synthesis \& What's Next” Billboard, 19 August 2014, <https://www.billboard.com/articles/columns/chart-beat/6221915/ sophie-producer-interview>, consulted 20 March 2019.

Wolfson, Sam, "PC Music: the future of pop or 'contemptuous parody'?", The Guardian, 2 May 2015, <https://www.theguardian.com/music/2015/may/02/pc-music-dance-music-collective>, consulted 20 March 2019.

\section{NOTES}

1. Stephen Graham, Sounds of the Underground: A Cultural, Political and Aesthetic Mapping of Underground and Fringe Music (Ann Arbor, MI, U. of Michigan P., 2016), p. 11.

2. Graham, pp. 23-4.

3. Hesmondhalgh, David. "Post-Punk's attempt to democratize the music industry: The success and failure of Rough Trade", Popular Music 16, 3 (1998), pp. 255-274, p. 258.

4. Hwanho Choi, The New Wave of Independent Labels, Dissertation (Liverpool: Liverpool University, 2009), <http://enoughrecords.scene.org/netaudio/Hwanho_Choi__he_New_Wave_of_Independent_Labels__Dissertation_.pdf>, consulted 25 March 2016, p. 12.

5. David Hesmondhalgh, 1998, p. 258.

6. Established in Birmingham in 1964.

7. Bill Osgerby, "Issues and Debates", in Subcultures, Popular Music and Social Change (Newcastle, Cambridge Scholars publishing, 2014), pp. 1-47, p. 16.

8. Graham, p. 18.

9. Quoted in David Hesmondhalgh, "Flexibility, Post-Fordism and the Music Industry", Media culture and Society, 18 (1996), pp. 469-488, pp. 482-3.

10. Alison Wenham, "Independent Music is now a growing force in the global market", Musicindie.com. 1 February 2014, <http://www.musicindie.com/independent-music-now-growingforce-global-market/>, consulted 20 March 2019.

11. Negus notes that affecting all minor companies, despite differing sizes of operation, is the problem of distribution. Keith Negus, Music Genres and Corporate Cultures (New York, Routledge, 1999) p. 58.

12. Anon, "Throbbing Gristle Second Annual Report Celluloid Lp", Popsike, no date, <https:// www.popsike.com/THROBBING-GRISTLE-Second-Annual-Report-CELLULOID-LP/ $380099070600 . h t m l>$, consulted 20 March 2019.

13. Keith Negus, p. 12.

14. Ryan Moore (2005), p. 233.

15. David Hesmondhalgh (1996), p. 474.

16. R. Strachan, "Micro-independent record labels in the UK: discourse, DIY cultural production and the music industry", European Journal of Cultural Studies, 10, 2 (2007), pp. 245-264, pp. 257-8.

17. Graham, p. 22.

18. Peter Webb, "'Infected by the seed of post-industrial punk bohemia': Nick Cave and the milieu of the 1980s underground", Popular Music History, 3, 2, (2008), pp. 103-122, p. 106.

19. Greil Marcus, Lipstick Traces: a Secret History of the Twentieth Century (London, Secker \& Warburg, 1989).

20. Will Straw, "Above and below ground", Keep it Simple, Make it Fast! An approach to underground music scenes, Paula Guerra and Tania Moreira eds., proceedings of the 2014 KISMIF conference, 1, pp. 407-13, <https://ler.letras.up.pt/uploads/ficheiros/13184.pdf>, consulted 20 March 2019.

21. Jacques Derrida, "I have a taste for the secret", A Taste for the Secret, Giacomo Donis and David Webb eds. (Cambridge, Polity, 2001), pp. 4-92, pp. 58-9. See also Ginette Michaud, "La voix voilée. 
Derrida lecteur de soi (Fragment d'une lecture de Voiles)", Derrida lecteur, Ginette Michaud and Georges Leroux dir., Études françaises, $38: 1-2,2002$.

22. Ryan Moore, "Alternative to What? Subcultural capital and the commercialization of a music scene", Deviant Behavior, 26: 3 (2005), pp. 229-52, p. 232.

23. Simon Reynolds, "New Pop and its Aftermath", On Record: Rock, Pop and the Written Word, Simon Frith and Andrew Goodwin eds. (London, Routledge, 1985), pp. 466-71.

24. David Hesmondhalgh (1998), pp 264-5.

25. Dick Hebdige, Subculture: the meaning of style (London, Routledge, 1991).

26. Keith Negus, "Where the Mystical Meets the Market: Commerce and Creativity in the Production of Popular Music", The Sociological Review, 47, 2 (1999), pp. 316-41, p. 320.

27. Moore, 2005, pp. 231-2.

28. Graham, p. 64.

29. Simon Frank, "Corporate DIY: PC Music and Performing Professionalism", LEAP 34, 11 December 2015, <http://www.leapleapleap.com/2015/12/corporate-diy-pc-music-andperforming-professionalism/>, consulted 20 March 2019.

30. Sam Wolfson, "PC Music: the future of pop or 'contemptuous parody'?", The Guardian, 2 May 2015, <https://www.theguardian.com/music/2015/may/02/pc-music-dance-music-collective>, consulted 20 March 2019.

31. Adam Harper, “The online underground: A new kind of punk?", Resident Advisor, 22 Sep 2014, <https://www.residentadvisor.net/features/2137>, consulted 20 March 2019.

32. Sohrab Golsorkhi-Ainslie, "Radio Tank Mix: A. G. Cook", no date, <https:// tankmagazine.com/tank/live-archive-music/radio-tank-mix-a-g-cook/>, consulted 20 March 2019.

33. Michelle Lhooq, "Pop Producer SOPHIE on Anonymity, Honesty, and Artifice", Teen Vogue, 7 December 2017, <https://www.teenvogue.com/story/sophie-producer>, consulted 20 March 2019.

34. Kristin Westcott Grant, "U.K. Producer SOPHIE Q\&A: On Secrecy, Synthesis \& What's Next" Billboard, 19 August 2014, <https://www.billboard.com/articles/columns/chart-beat/6221915/ sophie-producer-interview>, consulted 20 March 2019.

35. Sasha Geffen, "Sophie Can Show You the World, and she's changing pop music in the process", Vulture, December 2017, <https://www.vulture.com/2017/12/profile-sophie.html>, consulted 20 March 2019.

36. Arguably, the post-punk movement had already problematized the dichotomy mainstream/ underground, especially on the occasion of the second British invasion, when the British wave of synth pop rode the American charts with their flamboyant performance of Hollywoodian splendor, leaving its audience unsure about the seriousness of their intent.

37. Simon Reynolds, "Bring the noise: an interview with Simon Reynolds", Fact Magazine, 18 April 2007, <www.factmagazine.co.uk/da/53579>, consulted 20 March 2007.

38. Sam Wolfson, "PC Music: the future of pop or 'contemptuous parody'?", The Guardian, 2 May 2015, <https://www.theguardian.com/music/2015/may/02/pc-music-dance-music-collective>, consulted 20 March 2019.

39. According to Thornton who elaborates on Bourdieu's concept of capital de prestige. Sarah Thornton, Club Cultures: Music, Media and Subcultural Capital (Cambridge, Blackwell, 1995).

40. Stephen Frith, Howard Horne, Art into Pop (London, Methuen, 1987). 


\section{ABSTRACTS}

This article addresses the question of the relationship between the underground and the mainstream through two examples bracketing the period under consideration (1977-82 on the one hand and 2014- on the other). The first example concerns the establishment in Great Britain of an independent production and distribution network associated with the punk and post-punk scenes. The second consists of a subcultural formation on a smaller scale served by a promotional approach which has the particularity of relying almost exclusively on digital communication.

While claiming a musical radicality that distinguished them from a more generalist production, both have come to negotiate an intermediate position between the oppositional strategies associated with the underground and a growing popularity, betraying an ambivalence on the subject of their inclusion in a market or commercial network.

Cet article aborde la question du rapport de l'underground au mainstream à travers deux exemples bornant la période considérée (1977-82 d'une part et 2014- de l'autre). Le premier exemple concerne l'établissement en Grande Bretagne d'un réseau indépendant de production et de diffusion associé aux scènes punk et post-punk. Le second consiste en une formation subculturelle de moindre ampleur servie par une démarche promotionnelle qui a la particularité de reposer presque exclusivement sur une communication digitale.

Tout en se revendiquant d'une radicalité musicale qui les distinguait d'une production plus généraliste, l'un et l'autre en sont venus à négocier une position intermédiaire entre la stratégie oppositionnelle associée à l'underground et une popularité grandissante, témoignant d'une ambivalence quant à leur inscription dans un marché ou un réseau commercial.

\section{INDEX}

Mots-clés: post-punk, indie, alternatif, PC Music, Rough Trade

Keywords: post-punk, indie, alternative, PC Music, Rough Trade

\section{AUTHOR}

\section{PHILIPPE BIRGY}

Laboratoire CAS, Université Toulouse-Jean Jaurès

Philippe Birgy est professeur à l'université de Toulouse-Jean Jaurès où il enseigne dans les champs du modernisme et des cultures populaires britanniques. Il est l'auteur de Mouvement techno et transit culturel et de divers articles sur les musiques populaires électroniques (Notamment « 'ZYX music.' Les dérives continentales de l'italo disco », Volume! 15 1, 2018 et « 'Si cette histoire vous amuse, on peut la recommencer.' Le yéyé et l'importation de la contre-culture américaine ", Volume! 9. 1, 2012.) Il a récemment dirigé un volume critique consacré aux héritages de David Bowie (Miranda 17, 2018). 